\title{
ROLA CULTURAL DEFENCE W WYMIARZE SPRAWIEDLIWOŚCI KARNEJ
}

\section{WSTEP}

Współcześnie wiele państw świata boryka się z problemem imigracji. Mimo zapewnień polityków, że dzięki wielokulturowemu społeczeństwu obywatele uczą się nawzajem tolerancji, a najważniejszym zadaniem rządów jest zapewnienie programów pozwalających na unifikację przybyszów z kulturą kraju imigracji, to jednak nie sposób nie dostrzec, że nie zawsze to ,wrastanie” w zastane społeczeństwo odbywa się bezproblemowo. Istnieją bowiem liczne grupy, które od początku są odporne na asymilację i żyją w zamkniętych wspólnotach, tworząc swoiste enklawy, bądź też na pozór normalnie funkcjonują w społeczeństwie, ale z bardzo silnym poczuciem swojej tożsamości kulturowej. Takie postawy moga stanowić problem dla reszty obywateli wielu dziedzinach życia społecznego, w tym także prawa, a zwłaszcza prawa karnego. Jednej z takich kwestii dotyka instytucja ,obrony przez kulturę” (cultural defence $)^{1}$.

\section{Pojęcie cultural defence}

Koncepcja cultural defence zakłada, że osoba wywodząca się z mniejszości kulturowej, w której w codziennym zachowaniu widać przejawy norm właściwych jej kulturze, nie powinna być uważana za w pełni odpowiedzialną za swój czyn, jeśli narusza on prawo państwa, w którym przebywa, jeżeli tylko taki czyn jest zgodny z nakazami jej kultury ${ }^{2}$.

Elementami koniecznymi, które muszą pojawić się przy odwołaniu do tej instytucji, są więc: przynależność do mniejszości kulturowej (zarówno ofiary, jak i sprawcy; faktyczna więź z daną grupa - problem ten będzie jeszcze poruszony); funkcjonowanie w ramach tej mniejszości jakiegoś wzorca zachowania, które mimo że przez członków danej wspólnoty jest w pełni akceptowane, pozostaje w sprzeczności z prawem państwowym; wpływ danego wzorca na zachowanie jednostki ${ }^{3}$.

\footnotetext{
${ }^{1}$ J. Zajadło, Fascynujace ścieżki filozofii prawa, Warszawa 2008, s. 69-70.

2 A. Phillips, When Culture Means Gender: Issues of Cultural Defence in English Courts, „The Modern Law Review” 2003, s. 512.

3 J. Zajadło, op. cit., s. 72.
} 
Nie można jednak traktować instytucji cultural defence jak prostego schematu i stosować ją, ilekroć w sprawie pojawia się czynnik „obcej” kultury, ponieważ, jak już zaznaczono, musi istnieć więź między czynem a kulturową tożsamością sprawcy ${ }^{4}$.

Można mówić o cultural defence $\mathrm{w}$ ujęciu wąskim, odnosząc tę instytucję tylko do spraw karnych, w szerszym znaczeniu na cultural defence można powoływać się także w sprawach cywilnych lub administracyjnych ${ }^{5}$. Na potrzeby tej pracy przyjęte zostało to pierwsze ujęcie.

Ponieważ polskie tłumaczenie zwrotu cultural defence jako ,obrona przez kulturę" nie oddaje w pełni semantycznie angielskiej nazwy, na gruncie tej pracy wykorzystane zostanie nazewnictwo w oryginalnej wersji językowej.

\section{Problem subkultur przestepczych (delinquent subcultures)}

Subkultury przestępcze są grupami, które identyfikują się z pewnymi wartościami odrębnymi od wyznawanych przez resztę społeczeństwa. Różnica ta objawia się na gruncie podejścia do systemu prawa i dóbr chronionych zwłaszcza przez prawo karne. Takie struktury nie będą jednak nigdy mogły odwoływać się do argumentów związanych z cultural defence, ponieważ - jak sama nazwa wskazuje - są to subkultury, a nie kultury w pełnym tego słowa znaczeniu. Powoływanie się przez te grupy na jakiekolwiek normy moralne zawsze będzie pozostawać w jakimś związku z przekonaniami pozostałej części społeczeństwa, nawet gdy są one dokładną negację poglądów większości ${ }^{6}$. Poza tym, mimo tych różnic, grupy te podzielają większość mniej spornych wartości, zakorzenionych $\mathrm{w}$ społeczeństwie. Tak więc, jak już stwierdzono, cultural defence nie może zostać wykorzystana $\mathrm{w}$ odniesieniu do takich grup.

\section{Debata nad cultural defence}

Cultural defence jest instytucją relatywnie nową. Pierwsze przypadki, gdy zaczęto powoływać się na przynależność kulturową sprawców przestępstw, sięgają lat $80 . \mathrm{XX}$ w. Niemniej jednak w ciągu trzydziestu lat, które od tego czasu minęły, ożywiła się debata nad sensem stosowania takich „kulturowych” argumentów, dzieląc praktyków i teoretyków na dwa obozy, wyrażające skrajne opinie na ten temat: od postulatów formalnego uznania cultural defence, a nawet stworzenia nowego rodzaju przestępstw, po postulaty wykluczenia obrony przez kulturę z sal sądowych ${ }^{7}$. Dyskusja o dopuszczalności cultural defence najżywiej toczy się w Stanach Zjednoczonych, gdzie po raz pierwszy

\footnotetext{
${ }^{4}$ J. Van Broeck, Cultural Defence and Culturally Motivated Crimes (Cultural Offences), „European Journal of Crime, Criminal Law and Criminal Justice" 9, 2001, nr 1, s. 29.

${ }^{5}$ S. Sykuna, J. Zajadło, Kontrowersje wokót tzw. obrony przez kulture -okoliczność wyłaczajaca winę, okoliczność tagodzaca czy nadużycie prawa do obrony?, „Przegląd Sądowy” 2007, czerwiec, s. 27.

6 J. Van Broeck, op. cit., s. 27.

7 A. Phillips, op. cit., s. 511.
} 
wykorzystano takie argumenty kulturowe i gdzie wskazuje się, że jest ona nieodłączną częścią pluralistycznego społeczeństwa amerykańskiego ${ }^{8}$.

Niezależnie jednak od tego, jakie stanowisko w tej debacie przyjać, nie da się ukryć, że ,cultural defence wyraża adaptację współczesnego prawa karnego do zjawiska wielokulturowości” 9 .

\section{PROBLEMY Z CULTURAL DEFENCE NA GRUNCIE PRAKTYKI}

\section{Prawo a aspekt kulturowy}

Można by zaryzykować stwierdzenie, że w większości przypadków prawo współczesnych państw nie jest przygotowane na konieczność uwzględnienia odmienności w stosunku do dominującej w państwie opcji kulturowej, i to nie tylko przy wydawaniu wyroków merytorycznych, ale w ogóle przy stosowaniu jakichkolwiek procedur prawnych. Sądy są nieprzygotowane do tego, że muszą brać pod uwagę aspekt kulturowy sprawy, do tego, że w ogóle może pojawić się jakiś problem $\mathrm{z}$ rozbieżnością $\mathrm{w}$ rozumieniu przepisów czy formalnych wymagań stawianych przez instytucje prawa, jak również do tego, że w sytuacji takich różnic należałoby odwołać się do specjalistów, na przykład antropologów. Antropologia bowiem ,powinna stać się [...] nauką pomocniczą dla nauk prawnych, orientujaca $\mathrm{w}$ stanowieniu norm realnych i optymalnych $\mathrm{w}$ danej kulturze oraz w sposobie ich kulturowej percepcji" ${ }^{10}$. Sądom problemy może sprawiać pisownia nazwisk dokonana za pomoca niespotykanego alfabetu, nieprecyzyjne wskazywanie na daty zdarzeń przez posługiwanie się odmiennym od kalendarza gregoriańskiego sposobem liczenia czasu, korzystanie ze specyficznej terminologii przy wskazywaniu na rodzinne pokrewieństwo czy właściwa tylko danej kulturze klasyfikacja chorób ${ }^{11}$. Z punktu widzenia prawa może okazać się problematyczne noszenie tradycyjnych strojów (na przykład casus Sikhów, którzy zobligowani są przez swoją religię do noszenia turbanów w Wielkiej Brytanii rozwiązano to, zwalniając ich z obowiązku ,,noszenia kasku na budowie czy podczas kierowania motocyklem"12) albo specyficzny sposób przygotowywania jedzenia (na przykład w kulturze muzułmańskiej praktykuje się domowy ubój zwierząt ${ }^{13}$ ).

Zwykle społeczeństwo jest niechętne mniejszościom, które starają się odnaleźć swoje miejsce w państwie. Rodzimi mieszkańcy są bowiem w stanie zaakceptować tylko te aspekty obcej kultury, które pokrywają się z powszechnym

\footnotetext{
${ }^{8}$ Note: The Cultural Defense in the Criminal Law, „Harvard Law Review” 99, 1986, nr 6, s. 1301.

9 M. Demain, Fictions of Intentions in the „Cultural Defense”, „American Anthropologist” 110, 2008, nr 4 , s. 433.

${ }^{10}$ O. Sitarz, Cultural defence a polskie prawo karne, ,Archiwum Kryminologii” 29-30, 2007-2008, s. 645 .

${ }^{11}$ A. Good, Cultural Evidence in Courts of Law, „Journal of the Royal Anthropological Institute" 2008, s. S56.

12 O. Sitarz, op. cit., s. 646.

13 Ibidem.
} 
wyobrażeniem o takiej mniejszości. Należałoby jednak zadać pytanie, czy wtedy jeszcze w ogóle mówimy o akceptacji, czy po prostu o bezmyślnym powtarzaniu często niepopartych faktami opinii. Zatem to, w jaki sposób wymiar sprawiedliwości podchodzi do uwzględniania czynników kulturowych, ma swoje korzenie $\mathrm{w}$ ogólnym nastawieniu społeczeństwa ${ }^{14}$. I właśnie $\mathrm{w}$ tym powinno przejawiać się określenie „sprawiedliwy” przy pojęciu systemu prawa - gdyż w przeciwieństwie do stereotypowego podejścia ogółu, sądy powinny pamiętać o tym, że na przepisy, na których się opieraja, niekoniecznie składają się wartości wyznawane przez wszystkie grupy społeczne w społeczeństwie pluralistycznym, i w związku z tym ważne jest „dopełnienie” tej sprawiedliwości $\mathrm{w}$ praktyce.

\section{Rzeczywista więź czynu z praktykami danej kultury}

Rozważając tę kwestię, należałoby oddzielić od siebie dwa problemy. Pierwszy dotyczy możliwości udowodnienia, że to, na co oskarżony się powołuje, rzeczywiście stanowi jeden z przyjętych i akceptowanych schematów zachowania w obrębie grupy, z której się wywodzi. Postrzeganie przez oskarżonego czynu $\mathrm{w}$ kategoriach kulturowych powinno zostać więc zobiektywizowane powinien on udowodnić, że pozostali członkowie jego kultury, podobnie jak on, akceptują specyficzne okoliczności i sposób popełnienia przestępstwa przez oskarżonego ${ }^{15}$, a sposób jego reakcji według kryteriów tej grupy był właściwy w danych okolicznościach. Takie spojrzenie na zachowanie oskarżonego powoduje, że zostaje ono porównane $\mathrm{z}$ ogólnymi standardami obowiązującymi w danej mniejszości. Trudne byłoby oczywiście uzyskanie jednolitego obrazu praktyki, ale nie jest to tutaj wymagane - wystarczy poznać odczucia większości.

Drugi problem wiąże się z rzeczywistą przynależnością do danej grupy kulturowej, a co za tym idzie - z rzeczywistą asymilacją oskarżonego z „,nowym” społeczeństwem. Może się bowiem zdarzyć, że osoba, która przez wiele lat żyje zgodnie ze standardami prawnymi czy moralnymi danego państwa, dopiero w obliczu aktu oskarżenia próbuje usprawiedliwić swój czyn, wskazując na tożsamość kulturową, nawet wtedy gdy faktyczne więzi między nią a mniejszością, z której pochodzi, zostały dawno zerwane. Jedną z propozycji rozwiązania tego typu problemów jest zwracanie uwagi na czas pobytu oskarżonego $\mathrm{w}$ danym państwie. $\mathrm{W}$ amerykańskiej debacie nad cultural defence pojawia się nawet jego precyzyjne określenie: 5 lat (natomiast w przypadku osób starszych, które sa mniej gotowe na szybkie przystosowanie się do nowych warunków 10 lat) od momentu przyjazdu do Stanów Zjednoczonych, po upływie których cultural defence nie powinna być brana pod uwage ${ }^{16}$. Takie propozycje

\footnotetext{
${ }^{14}$ S. D'hondt, The Cultural Defense as Courtroom Drama: The Enactment of Identity, Sameness, and Difference in Criminal Trial Discourse, „Law \& Social Inquiry” 35, 2010, Winter, s. 68-69.

15 J. Van Broeck, op. cit., s. 24.

${ }^{16}$ A. Phillips, op. cit., s. 513.
} 
pozbawione sa jednak większego sensu, ponieważ nie da się określić, ile czasu potrzebuje członek marginalizowanej kulturowo grupy, aby całkowicie zintegrować się z dominującymi standardami ${ }^{17}$. Są to bardzo indywidualne sprawy i nie można stosować takich uogólnień.

\section{WYŁACCZENIE ODPOWIEDZIALNOŚCI KARNEJ ALBO JEJ ZLAGODZENIE}

\section{Błąd w zakresie nieświadomości bezprawności czynu}

Błąd w zakresie nieświadomości bezprawności czynu pojawia się, gdy sprawca, wypełniając wzorce zachowań przyjęte w jego kulturze, nie zdaje sobie sprawy, że łamie jednocześnie prawo pozytywne obowiązujące w danym państwie ${ }^{18}$. Oczywiście, biorąc pod uwagę zasadę ignorantia iuris nocet, nie można zrezygnować zupełnie $\mathrm{z}$ pociągnięcia takiego sprawcy do odpowiedzialności, jednocześnie jednak niesprawiedliwe byłoby zakazanie powoływania się na nieznajomość powszechnie obowiązującego prawa osobie wychowanej w innej kulturze niż ta, której wartości są obecne w prawie. Można by się spierać, czy taki argument jest dopuszczalny w odniesieniu do osoby, która od dziecka wychowywała się $\mathrm{w}$ danym kraju i w związku z tym była poddana socjalizacji tak jak wszyscy pozostali obywatele, ale trudno odmówić go imigrantowi nowo przybyłemu do obcego mu państwa ${ }^{19}$.

Przykładem może być sprawa Irakijczyka mieszkającego w Stanach Zjednoczonych, który postanowił wydać za mąż dwie córki (wówczas w wieku 13 i 14 lat) za irackich imigrantów (28 lat i 34 lata). Oskarżony o znęcanie się nad dziećmi, przed sądem twierdził, że nie ma nic złego w aranżowanych małżeństwach, które są bardziej rozsądne od zwyczajowej praktyki amerykańskiej. Gdy dzieci sprzeciwiły się woli ojca, zagroził, że zabije je albo odeśle do Iraku. Wtedy dziewczynki poprosiły o interwencję irackiego przyjaciela, który uświadomił ojcu, że takie małżeństwa są nielegalne w Stanach Zjednoczonych, ale też nie udało mu się zmienić jego nastawienia. Ojciec cały czas trwał w przekonaniu, że taki zaaranżowany związek jest obowiązująca normą w jego kulturze, a w związku z tym jest słuszny i dopuszczalny. Slub ostatecznie doszedł do skutku, a małżeństwa zostały skonsumowane. Sprawa skończyła się wyrokami więzienia, odpowiednio 4 i 6 lat, za molestowanie seksualne dziecka pierwszego stopnia, mimo że początkowo postawiono zarzuty zgwałcenia. Obaj skazani, podobnie jak ojciec dziewczynek, twierdzili, że nie zdawali sobie sprawy, iż łamią prawo, ponieważ taki sposób zawierania małżeństw jest powszechnie akceptowany w ich kraju ${ }^{20}$.

Na gruncie polskiego Kodeksu karnego błąd co do prawa rozważa się na podstawie art. 30. Ustawodawca uzależnia przestępność czynu objętego błędem

\footnotetext{
17 M. Demain, op. cit., s. 435-436.

18 S. Sykuna, J. Zajadło, op. cit., s. 28.

19 Note, s. 1299.

${ }^{20}$ M. P. Golding, The Cultural Defense, ,Ratio Juris” 15, 2002, nr 2 (June), s. 150-151.
} 
od możliwości usprawiedliwienia nieświadomości bezprawności. Jeżeli bowiem nieświadomość jest usprawiedliwiona, sprawca czynu objętego błędem nie popełnia przestępstwa; jeżeli jest nieusprawiedliwiona - sąd może zastosować nadzwyczajne złagodzenie kary. Ocena nieświadomości musi być zindywidualizowana, uwzględniać, ,czy konkretny sprawca, w konkretnych okolicznościach mógł sobie uświadomić bezprawność przedsięwziętego czynu" ${ }^{21}$. Kryterium usprawiedliwionej nieświadomości nie zostanie też spełnione, jeżeli sprawca, mimo takiej możliwości, nie zapoznał się z obowiązującym prawem ${ }^{22}$. Wydaje się więc, że jeśli analogiczna sytuacja miałaby miejsce pod rządami polskiego Kodeksu karnego, trudno byłoby powołać się w obronie na błąd co do prawa, przynajmniej w odniesieniu do ojca, który nawet jeżeli przez lata mieszkania w obcym kraju nie zdążył zorientować się w tamtejszym systemie prawa karnego, to i tak $\mathrm{w}$ tej konkretnej sytuacji został wyraźnie poinformowany o przestępności czynu. Jego błędu nie można uznać za usprawiedliwiony, natomiast można zastanawiać się nad zakwalifikowaniem go jako nieusprawiedliwiony, właśnie przez siłę działania imperatywu kulturowego.

Generalnie jednak w odniesieniu do cultural defence można wyobrazić sobie sytuację, w której na przykład nowo przybyły do polski imigrant (pochodzący z kraju, w którym aksjologia systemu prawnego różni się od przyjętych w Polsce wartości, a ponadto nieznający języka polskiego) dopuszcza się czynu powszechnie akceptowanego w jego kulturze, nie zdając sobie sprawy, że swoim zachowaniem narusza polskie prawo karne. Pojawi się wówczas możliwość powołania się na usprawiedliwioną nieświadomość bezprawności czynu.

\section{Cultural defence jako okoliczność łagodząca}

Wpływający na zachowanie sprawcy ,,imperatyw kulturowy” może zostać uwzględniony przy wymiarze kary także jako okoliczność łagodząca w ramach nadzwyczajnego złagodzenia kary lub, odpowiednio do niższego stopnia społecznej szkodliwości, w ramach ustawowego zagrożenia karą ${ }^{23}$. Czasami bowiem sama świadomość sprawcy, że dopuszcza się czynu niezgodnego z prawem, nie wystarcza, aby przemóc się i zrezygnować z realizacji wzorca zachowania przyjętego w rodzimej kulturze. Sprawca może czuć się moralnie zobligowany do postapienia zgodnie $\mathrm{z}$ wartościami wpajanymi mu $\mathrm{w}$ jego środowisku ${ }^{24}$.

Jako przykład może posłużyć sprawa 59-letniego Turka oskarżonego przed sądem w Belgii o zabójstwo krewnego. Tłem dla sprawy były nieporozumienia w rodzinie dotyczące niespłaconego posagu. Ostatecznie mężczyzna został skazany na rok pozbawienia wolności, co było najniższa kara, na jaka gotowy był się zgodzić prokurator. Sąd wziął pod uwagę argumenty obrony, która starała się wykazać, że kultura, której wartości wyznawał oskarżony, nie pozwalała mu w danej sytuacji zachować się inaczej, zwłaszcza biorąc pod

\footnotetext{
${ }^{21}$ A. Marek, Kodeks karny. Komentarz, Warszawa 2010, s. 106.

${ }^{22}$ Ibidem, s. 107.

${ }^{23}$ O. Sitarz, op. cit., s. 651.

${ }^{24}$ Note, s. 1300 .
} 
uwagę znaczenie honoru i zwyczajów. Podnoszono także, że pochodzenie ze słabo rozwiniętego rolniczego regionu Turcji potęguje przywiązanie oskarżonego do tradycyjnych wartości i więzi rodzinnych ${ }^{25}$.

\section{Błąd co do faktu}

Powoływanie się na cultural defence jest możliwe także wtedy, gdy wystąpił „błąd co do faktu, w sytuacji, gdy sprawca działał w przekonaniu, że jego działanie mieści się w granicach odrębności kulturowej, podczas gdy w rzeczywistości jest inaczej”" 26 .

Ilustracja takiej sytuacji jest sprawa People v. Moua, która toczyła się w Stanach Zjednoczonych. Oskarżony dopuścił się porwania i gwałtu kobiety. Takie zachowanie, jego zdaniem, było częścią małżeńskiego rytuału praktykowanego wśród społeczności Hmong, z której zarówno on, jak i ofiara się wywodzili. Przed sądem Moua tłumaczył, że był przekonany, iż opór ze strony dziewczyny jest także w tym przypadku częścią tradycji. W związku z tym nie wziął pod uwagę, że rzeczywiście nie wyraża ona zgody na taki osobliwy sposób zawarcia małżeństwa. Sąd wziął pod uwagę argumenty oskarżonego i w ostateczności Moua został skazany za bezprawne pozbawienie wolności, a nie za porwanie i gwałt ${ }^{27}$.

Na gruncie polskiego Kodeksu karnego error facti wyraża art. 28, który stanowi, że nie popełnia umyślnie czynu zabronionego, kto pozostaje w błędzie co do okoliczności stanowiących jego znamię. Z orzecznictwa Sądu Najwyższego wynika, że błąd sprawcy „może dotyczyć każdego z przedmiotowych znamion czynu zabronionego, ale nie znamion podmiotowych" ${ }^{28}$, czyli może być związany $\mathrm{z}$ zewnętrznym zachowaniem się sprawcy, jego forma, okolicznościami oraz skutkiem ${ }^{29}$. Gdy więc sprawca mylnie ocenia zachowanie ofiary, odczytując je przez pryzmat wspólnej kultury (źle interpretuje jej reakcję i w związku z tym działa w błędzie), swoim zachowaniem nie wyczerpuje znamion czynu zabronionego. Sprawa mogłaby być wówczas rozpatrywana z korzyścią dla niego na gruncie art. 28 k.k.

\section{Niepoczytalność}

Czasowa niepoczytalność jest kolejnym argumentem, który może wpisywać się w strategię cultural defence. Oskarżony może skorzystać z niego, powołując się na fakt, że wartości, które są mu bliskie, tak dalece odbiegają od ,,wartości większości odzwierciedlonych w prawie karnym, że »zabrakło mu niezbędnego

${ }^{25}$ S. D'hondt, op. cit., s. 76-90.

${ }^{26}$ S. Sykuna, J. Zajadło, op. cit., s. 28.

${ }^{27}$ N. S. Kim, Blameworthiness, Intent, and Cultural Dissonance: The Unequal Treatment of Cultural Defense Defendants, „University of Florida Journal of Law \& Public Policy” 17, 2006, nr 2 (August), s. 209-210.

28 A. Marek, Kodeks..., s. 102.

${ }^{29}$ A. Marek, Prawo karne, Warszawa 2009, s. 113. 
rozeznania, żeby albo dostrzec przestępność swojego zachowania, albo dostosować się do wymogów prawa «"30.

Jako przykład można podać tutaj casus Fumiko Kimury, która dowiedziawszy się o niewierności męża, postanowiła popełnić zakorzenione w japońskiej tradycji oya-ko shinju: wspólne samobójstwo rodzica i dziecka. W wyniku próby utopienia dwójka jej dzieci poniosła śmierć, ona sama jednak przeżyła. Pierwotnie została oskarżona o morderstwo i przestępstwo sprowadzenia niebezpieczeństwa, ale ostatecznie skończyło się na zarzucie zabójstwa bez premedytacji (manslaughter) ${ }^{31}$. Wsparcia oskarżonej udzieliła społeczność japońska w Stanach Zjednoczonych, która przygotowała petycję z 25000 podpisami, w której poświadczono, że taka praktyka, jak oya-ko shinju, na gruncie kultury japońskiej rzeczywiście istnieje. Jednak adwokaci Kimury zamiast wykorzystać takie wsparcie do urzeczywistnienia cultural defence, odwołali się do czasowej niepoczytalności swojej klientki.

Należałoby rozważyć zasadność takiego argumentu. Z jednej strony, trudno stwierdzić, że istniejące w kulturze japońskiej przekonanie, iż można zmyć hańbę samobójstwem, świadczy o niepoczytalności tych, którzy tak sądzą. Może w ogóle budzić ogromne wątpliwości, gdy każe się wybierać oskarżonemu między powołaniem się na ułomność umysłową w związku z silnym poczuciem tożsamości kulturowej a byciem uznanym za przestępcę ${ }^{32}$ (niemniej jednak sąd przy wyrokowaniu wziął pod uwagę niepoczytalność Kimury).

$\mathrm{Z}$ drugiej strony, poczucie kulturowego imperatywu może być niekiedy tak silne, że spowoduje niemożność rozpoznania znaczenia czynu i pokierowania swoim postępowaniem lub znacznie je ograniczy. Polski Kodeks karny w art. 31 $\S 1$ i 2 określa warunki konieczne do stwierdzenia niepoczytalności i poczytalności ograniczonej. O niepoczytalności mówimy, gdy taki stan sprawcy został wywołany chorobą psychiczna, upośledzeniem umysłowym lub innym zakłóceniem czynności psychicznych. Dwie pierwsze podstawy niepoczytalności przy przestępstwach umotywowanych kulturowo nie będą miały zastosowania (oczywiście wyłączając sytuację, gdy sprawca popełnia przestępstwo na tle kulturowym, ale główna przyczyna jest choroba psychiczna lub upośledzenie umysłowe, a czynnik kulturowy pojawia się niejako ubocznie), natomiast można by rozważyć sytuację ,innego zakłócenia czynności psychicznych”. „Moga one mieć charakter chorobowy lub patologiczny (np. zapalenie opon mózgowych [...] albo charakter czysto fizjologiczny (np. odurzenie narkotykiem [...])" ${ }^{33}$, ale na pewno należy odróżnić od nich tak zwany afekt fizjologiczny, który stanowi znamię przestępstwa zabójstwa pod wpływem silnego wzburzenia (art. 148 $\S 4$ k.k.). Silne wzburzenie definiuje się jako ,stan psychiczny, w którym przeżywany przez sprawcę proces emocjonalny, wynikły ze szczególnej sytuacji motywacyjnej, w istotnym stopniu ogranicza kontrolne działanie intelektu" ${ }^{34}$.

\footnotetext{
${ }^{30}$ Note, s. 1294.

${ }^{31}$ N. S. Kim, op. cit., s. 204-206.

${ }^{32}$ M. Demain, op. cit., s. 435.

${ }_{33}$ A. Marek, Kodeks..., s. 109.

${ }^{34}$ Ibidem, s. 373.
} 
Wydaje się więc, że - przynajmniej na gruncie prawa polskiego - argument niepoczytalności, nawet ograniczonej (też bowiem opierającej się na trzech wymienionych przesłankach), byłby trudny do obronienia. Bardziej adekwatna do spraw z zastosowaniem cultural defence wydaje się konstrukcja działania pod wpływem silnego wzburzenia, ale i ona nie zawsze może być zastosowana, co zostało wskazane w punkcie IV.

\section{Cultural defence jako kontratyp pozaustawowy}

Kontratypy to okoliczności wyłączające bezprawność ,z powodu braku szkodliwości społecznej lub niecelowości karania [...] podjętych w ich ramach czynów wypełniających ustawowe znamiona czynu zabronionego" ${ }^{35}$. W Kodeksie karnym do kontratypów zalicza się: obronę konieczna, stan wyższej konieczności, dopuszczalne ryzyko, uzasadnioną krytykę uchylającą odpowiedzialność za zniesławienie i ostateczną potrzebę wojskową, oprócz tego można wymienić jeszcze szereg kontratypów pozakodeksowych, na przykład karcenie nieletnich $^{36}$.

Oprócz wspomnianych sytuacji, w doktrynie wyróżnia się także pojęcie kontratypów pozaustawowych, czyli okoliczności wyłączających bezprawność, nieuregulowanych w ustawach. Będą więc one wymagały powoływania się na normy niepisane, akceptowane przez dane społeczeństwo. Odwołanie się do nich będzie dopuszczalne, jeżeli takie źródło prawa ma zadziałać na korzyść oskarżonego ${ }^{37}$. Wśród najczęściej wymienianych kontratypów pozaustawowych wskazuje się na kontratyp topienia marzanny czy śmigusa-dyngusa. Sąd Najwyższy przytacza w takich sytuacjach obowiązywanie „odwiecznych zwyczajów", które nie moga powodować karalności czynu ani ograniczać swobody działania ${ }^{38}$.

Zastanawiając się nad dopuszczalnością kontratypów pozaustawowych w polskim prawie karnym, należy rozważyć argumenty za i przeciw takiej konstrukcji. Z jednej strony bowiem, można by wskazać na funkcję gwarancyjna prawa karnego, którą w tym wypadku stanowiłaby możliwość powołania się na normy niepisane, ale ważne $\mathrm{z}$ punktu widzenia okoliczności popełnienia czynu $^{39}$, a która nie wymaga uregulowania w ustawie wszystkich okoliczności wyłączających bezprawność czynu. Z drugiej jednak - akceptowanie przez sądy argumentów składających się na kontratyp pozaustawowy może zakrawać na wykonywanie przez nie uprawnień przyznanych ustawodawcy ${ }^{40}$. Poza tym należałoby wskazać na typowość danej sytuacji, akceptację czynu przez społeczeństwo (a przynajmniej grupę, w obrębie której czyn dokonano) oraz

35 A. Marek, Prawo..., s. 168.

${ }^{36}$ Ibidem, s. 168.

37 J. Warylewski, Zasada ustawowej określoności przestanek odpowiedzialności karnej a kontratypy pozaustawowe, w: J. Maciejewski (red.), Okoliczności wytaczajace bezprawność czynu (Materiały IV Bielańskiego Kolokwium Karnistycznego), Toruń 2008, s. 22.

${ }^{38}$ Ibidem, s. 25.

39 Ibidem, s. 26.

40 Ibidem. 
kolizję dóbr prawnych ${ }^{41}$. Dopiero zebranie tych wszystkich przesłanek razem mogłoby pozwolić na stworzenie konstrukcji kontratypu pozaustawowego, a więc jest to zadanie trudne, o ile nie niemożliwe do wykonania.

Jeżeli przyjąć jednak, że kontratyp pozaustawowy jest akceptowalny na gruncie polskiego prawa karnego, można odwołać się do następującej sprawy, która jednocześnie dotyka problemu cultural defence: przed Sądem Rejonowym w Kędzierzynie-Koźlu w 2005 r. toczył się proces, w którym 22-letni Rom został oskarżony o obcowanie płciowe z małoletnia poniżej 15 roku życia ${ }^{42}$. Z punktu widzenia tradycji romskiej nie robił on jednak nic złego, wcześniej bowiem zawarł związek małżeński z pokrzywdzoną, zgodny z romskim obrządkiem i ważny w ich kulturze. Sąd musiał wziąć pod uwagę argument kulturowy, orzekł bowiem karę 8 miesięcy pozbawienia wolności i zawiesił jej wykonanie na 3 lata. W ówczesnym stanie prawnym przestępstwo, o które Rom został oskarżony, było zagrożone karą od roku do 10 lat pozbawienia wolności, a więc sąd zastosował nadzwyczajne złagodzenie kary ${ }^{43}$. Taki przypadek można byłoby rozważyć jako ewentualny kontratyp pozaustawowy „o roboczej nazwie ślubu albo małżeństwa romskiego (cygańskiego), przy koniecznym wskazaniu na inne warunki m.in. na wymaganie dojrzałości płciowej u małoletniego" ${ }^{44}$.

\section{Wpływ czynników kulturowych na społeczną szkodliwość czynu}

Jak już zostało wspomniane, istnieje możliwość potraktowania kulturowego tła przestępstwa jako okoliczności łagodzącej w ramach ustawowego zagrożenia kara, biorąc pod uwagę odpowiednio niższy stopień szkodliwości społecznej czynu. Przy ocenie społecznej szkodliwości czynu sąd bierze pod uwagę znamiona zarówno strony podmiotowej, jak i przedmiotowej czynu, jak wskazuje art. 115 § 2 k.k. Dla cultural defence szczególne znaczenie miałyby wymienione w przepisie - z elementów strony przedmiotowej - sposób i okoliczności popełnienia czynu, a ze strony podmiotowej - motywacja sprawcy.

\section{NIEPRZYSTOSOWANIE SYSTEMÓW PRAWA DO POWOLYWANIA SIE NA CZYNNIK KULTUROWY}

Sprawa People v. Kimura obnażyła jeszcze jeden problem dotyczący cultural defence, a mianowicie brak w prawie właściwych konstrukcji, które pozwalałyby uwzględnić wpływ ,kulturalnego imperatywu”, jednocześnie biorąc w pełni pod uwage stan faktyczny sprawy.

\footnotetext{
${ }^{41}$ Ibidem, s. 27.

42 Ibidem, s. 34.

43 Ibidem, s. 34-35.

${ }^{44}$ Ibidem, s. 35.
} 
W kalifornijskim prawie „,morderstwo zostało zdefiniowane jako bezprawne pozbawienie życia istoty ludzkiej z premedytacja”" ${ }^{45}$. Premedytacja to bezprawny zamiar odebrania życia. Zabójstwem pod wpływem silnego wzburzenia (voluntary manslaughter) jest z kolei nazywane zabicie człowieka pod wpływem nagłej kłótni czy gwałtownych emocji (sudden quarrel, heat of passion). Znając te definicje, można spróbować wyjaśnić, co sąd dostrzegł w zachowaniu F. Kimury: skazując ja za zabójstwo bez premedytacji, ale pod wpływem silnego wzburzenia, uznał, że jej zachowanie nie było wynikiem zamiaru spowodowania czyjejkolwiek śmierć. Trudno jednak uznać taki argument, ponieważ F. Kimura zdawała sobie sprawę, na czym polega oya-ko shinju, ponadto jej reakcja na zdradę męża nie wskazywała na nagły, niepohamowany przypływ emocji, wręcz przeciwnie - decyzja o tym, że jedynym wyjściem z sytuacji jest oya-ko shinju, nie mogła być nagłym impulsem, tylko wynikiem rozważenia jej położenia. Sąd jednak uznał, że skazanie jej za morderstwo byłoby niesprawiedliwe, gdyż w jej działaniu nie było premedytacji ${ }^{46}$.

Można mieć wątpliwości, czy dobrze świadczy o systemie prawa, sytuacja, gdy sąd, chcąc uwzględnić stan faktyczny i zamiar oskarżonego, musi wybiórczo traktować definicję jednego przestępstwa, aby uniknąć skazania za inne, jeszcze mniej nadające się do subsumpcji. W dalszej części tej pracy przyjdzie odpowiedzieć na pytanie, czy w ogóle, a jeśli tak to, w jakim stopniu, przepisy powinny brać pod uwagę możliwość pojawienia się niecodziennego argumentu, jakim jest wpływ czynnika kulturowego na zachowanie się sprawcy.

$\mathrm{Z}$ podobnymi problemami musiał zmierzyć się sąd w sprawie People v. Chen. Oskarżony Dong Lu Chen zabił swą żonę młotkiem, gdy dowiedział się o jej zdradach. Obrona twierdziła, że działanie Chena, biorąc pod uwagę zaistniałe okoliczności, było „,sensowne” (reasonable), ponieważ niewierność żony stanowi w chińskiej kulturze plamę na honorze męża. Początkowo postawiono mu zarzut morderstwa drugiego stopnia (second degree murder), które według prawa stanu Nowy Jork oznacza, że sprawca działał z zamiarem zabicia człowieka. Jednak po przeprowadzeniu dowodu, z którego wynikało, jakie znaczenie w kulturze chińskiej ma potępienie cudzołóstwa, sąd skazał Chena za zabójstwo drugiego stopnia (second degree manslaughter), które definiuje się jako lekkomyślne (recklessly) spowodowanie śmierci. Lekkomyślność z kolei pojawia się, gdy sprawca zdaje sobie sprawę z rzeczywistego i nieusprawiedliwionego ryzyka, ale świadomie je lekceważy ${ }^{47}$. Biorąc po uwagę, że Chen zadał żonie 8 ciosów młotkiem, należałoby zadać pytanie, co sąd rozumie w takim razie przez słowo „lekkomyślność”. Dla sądu jednak najważniejsza przesłanka prowadząca do złagodzenia podstawy skazania był fakt, że do przemocy Chen został popchnięty przez to, jak cudzołóstwo, zwłaszcza żony, jest postrzegane w społeczeństwie chińskim i jaki ma wpływ na wizerunek męża ${ }^{48}$.

\footnotetext{
${ }^{45}$ N. S. Kim, op. cit., s. 205-206.

${ }^{46}$ Ibidem, s. 206.

${ }^{47}$ Ibidem, s. 206-207.

${ }^{48}$ Ibidem, s. 208.
} 
Jak widać, także w tej sprawie sąd nie dysponował właściwymi narzędziami do wymierzenia kary proporcjonalnej do popełnionego czynu. Biorąc pod uwage „,imperatyw kulturowy”, skazanie za morderstwo pierwszego stopnia nie oddałoby wszystkich okoliczności sprawy, ale to, że działanie Chena zostało przez sąd uznane za lekkomyślne, też budzi sprzeciw. Można nie zgadzać się $\mathrm{z}$ takim wyrokiem, ale jednocześnie trudno wskazać, jaki inny zarzut $\mathrm{w}$ ramach obowiązujących przepisów byłby właściwy.

\section{CULTURAL DEFENCE A PRAWA KOBIET}

W literaturze dotyczącej cultural defence, obok problemów natury kulturowej czy prawnej w stosowaniu tego typu argumentów, często wskazuje się także na kwestię praw kobiet. Istnieje bowiem, według niektórych autorów ${ }^{49}$, niebezpieczeństwo zbyt pobłażliwego traktowania sprawców przemocy domowej za sprawą powoływania się przez nich na fakt, że w społeczności, z której się wywodza, obowiązuje model patriarchalny ${ }^{50}$, a w nim mężowi, jako głowie rodziny, należy się szczególny szacunek, a w związku z tym na przykład prawo ukarania żony za nieposłuszeństwo. Sądy rozpatrują więc przypadki, gdy zazdrosny mąż dusi żonę lub w okrutny sposób popełnia morderstwo (People $v$. Chen), ojciec wydaje za mąż nieletnie córki (opisana w punkcie III.1 sprawa aranżowanych małżeństw), mężczyzna uprowadza dziewczynę, a następnie gwałci (People v. Moua), a wszystko to ma wpisywać się w tradycję przyjęta w danej społeczności. Trafnie podkreśla się, że zwłaszcza w wypadku przemocy domowej trudno wskazać, czym różni się zabójstwo czy znęcanie, którego dopuszcza się mąż chcący bronić swojego honoru (mającego tak duże znaczenie w jego grupie odmiennej kulturowo od reszty społeczeństwa), od tego samego przestępstwa popełnianego przez członka dominującej $\mathrm{w}$ danym państwie kultury, który też na swój sposób chce „bronić” swojego honoru. Trudno dostrzec różnicę między pojawiającymi się w odrębnych kulturach motywacjami do takich czynów ${ }^{51}$. A $\mathrm{w}$ związku $\mathrm{z}$ tym pojawia się pytanie, dlaczego uwzględniać w takich sytuacjach cultural defence.

\section{PODSUMOWANIE}

W literaturze wyróżnia się trzy ujęcia kwestii kultury i problemu prawa. W pierwszym, prawo jest przeciwstawione kulturze, jako że istnieje fundamentalna rozbieżność między uniwersalnymi prawami a kulturowym relatywizmem. Jest to więc podejście charakterystyczne dla prawniczego pozytywizmu. W drugim ujęciu, mówi się o ,,prawie do kultury” jako jednym właśnie z tych uniwersalnych praw. Trzecie podejście z kolei traktuje dyskusję

\footnotetext{
${ }^{49}$ M. Demain, op. cit., s. 433; M. P. Golding, op. cit., s. 147; N. C. Kim, op. cit., s. 200.

50 A. Phillips, op. cit., s. 511.

${ }^{51}$ N. C. Kim, op. cit., s. 208.
} 
o prawach i praktyce jako pewien proces kulturowy, w wyniku którego to prawo jest utożsamiane $\mathrm{z}$ kulturą ${ }^{52}$.

Pytanie, jakie należałoby więc zadać, dotyczy tego, jak na kulturę powinny zapatrywać się sądy. Trudno jednak nakazać wymiarowi sprawiedliwości ustosunkowanie się tylko do jednego z powyższych ujęć problemu, gdyż w optymalnej sytuacji wszystkie trzy stanowiska powinny być wzięte pod uwagę: najpierw należy dostrzec konflikt prawo - kultura, potem uznać, że każdy ma prawo do zachowania swojej tożsamości kulturowej, a następnie przeprowadzić na sali sądowej spór, który będzie wkładem do rozwoju postrzegania zjawiska wielokulturowości w społeczeństwie.

Uregulowanie cultural defence w kodyfikacji prawa jest bardzo trudne, żeby nie powiedzieć niemożliwe, do dokonania. Lista problemów, jakie należałoby uwzględnić jest długa, poczynając od tego, czy instytucja cultural defence powinna zostać uwzględniona już na etapie prawa materialnego, jako pewne ,,przestępstwo motywowane kulturowo”, czy dopiero na etapie procesu karnego. W następnej kolejności trzeba byłoby wskazać, czy każda grupa utożsamiana z inną kulturą niż dominująca w danym państwie powinna zostać uwzględniona przy cultural defence, czy tylko niektóre, a jeśli tak, to jakie. W związku z tym nasuwa się pytanie, czy próbować stworzyć normę ogólną dla wszystkich mniejszości kulturowych, uniwersalnie uwzględniająca odmienne od dominujących wartości, choć może różnice między nimi okażą się na tyle nie do pogodzenia, że i to okaże się niemożliwe. Jak widać, jedna kwestia rodzi kolejne, coraz bardziej problematyczne. Dlatego należy porzucić rozważania o stworzeniu przestępstwa w ramach cultural defence na rzecz praktyki, gdyż nawet wtedy, gdy prawo skodyfikowane ,nie uznaje roli czynników kulturowych, [...] alternatywne mechanizmy moga pozwalać, aby system prawny uwzględniał te czynniki w określaniu ostatecznej sankcji, którą należy zastosować" ${ }^{53}$. Choć oczywiście zawsze wskazana jest duża rozwaga sadów w podejściu do cultural defence, żeby nie doprowadzić do sytuacji, w której jest ona traktowana jako pewna pomoc w uniknięciu kary ${ }^{54}$.

Uwzględnienie argumentów kulturowych w praktyce przede wszystkim ma na celu sprawiedliwy osąd czynu oskarżonego, ale także może stanowić swoistą instrukcję dla pozostałych członków danej grupy i spełniać rolę w zakresie prewencji ogólnej ${ }^{55}$.

Jak wskazano powyżej, problemem jest określenie, którą instytucję prawa połączyć z cultural defence, ponieważ każda taka sytuacja ma swoje zalety i wady. Niemniej jednak to, że praktyczne wykorzystanie cultural defence nie jest proste, nie powinno być przyczyną całkowitego odrzucenia argumentów ,kulturowych”.

Agata Kleczkowska

Uniwersytet Mikotaja Kopernika w Toruniu

ag.kleczkowska@gmail.com

\footnotetext{
${ }^{52}$ A. Good, op. cit., s. S52.

53 Note, s. 1295.

54 Ibidem, s. 1303.

55 Ibidem.
} 


\section{THE ROLE OF ‘CULTURAL DEFENCE’ IN CRIMINAL JURISDICTION}

\section{Summary}

The phenomenon of multiculturalism has its reflection in the growing importance of the concept of 'cultural defence' which is present in criminal jurisdiction. It means that a court will take into account the defendant's cultural roots that might have influenced his behaviour. The debate in a courtroom regarding such cultural arguments touches upon the dogmatic as well as practical issues. While deliberating matters in which the 'cultural defence' appears, courts should first and foremost rule if the defendant can refer to such motivation of his actions at all. Next, the court must decide how to account for the cultural factor: whether as the cause for insanity, error facti, or error concerning the ignorance of law, etc. Agreeing upon both the facts of the case and fair assessment of the action may be a difficult task under the present legal system. It is also important not to allow to use 'cultural defence' against women's rights. Codifying crimes with cultural basis may turn out impossible to achieve. Therefore, when carrying out proceedings, organs of the administration of justice should remember about the cultural background of certain crimes. 